\title{
The Use of Magic and Fairy Tale Dice to Improve Students' Ability in Writing Narrative Text
}

\author{
Arbain Arbain \\ English Department \\ Universitas Widya Gama Mahakam Samarinda \\ Samarinda, Indonesia \\ baintigers@gmail.com
}

\author{
Dedi Rahman Nur \\ English Department \\ Universitas Widya Gama Mahakam Samarinda \\ Samarinda, Indonesia \\ d.blues84@gmail.com
}

\begin{abstract}
This research done at first semester students of English Department Widya Gama Mahakam Samarinda aimed at finding out whether or not magic and fairy tale dice can game improve students' ability in producing a better narrative text. The research was classroom action research. This research employed classroom action research in the forms descriptive quantitative design. Data were obtained by giving test to the first semester students of English department of Widya Gama Mahakam University before and after the lecture using magic and fairy tale dice. The instruments that were used to collect the data were test as a main instrument and observation checklist as second instrument. The test was used to know students ability in writing narrative text before and after the lecture implementing the use of magic and fairy tale dice. The findings of this study show that, magic and fairy tale dice can be incorporated in writing narrative text. The students can catch the idea because the game will stimulate the imaginations of students. Using magic and fairy tale dice game can be a new atmosphere for the students who have not been taught using a new game before. After the students motivate to study the material, it will revive their imagination to create a narrative text.
\end{abstract}

Keywords-Magic and fairy tale dice game; writing; narrative

\section{INTRODUCTION}

Writing is one of the difficult skills that students face in their non-verbal communication. It happens because the course of writing requires the ability of students to produce language and express the concepts in written form. Based on the writer's observations and experience in teaching, it shows that their difficulties associated with their primary and secondary education students, which rarely get the task to construct or make writing so that they are not trained to produce language. Indeed, the experience of students with first language is not much different from the experience with a new language, or better known as second language. From the study of Second Language Acquisition, the writers realized that the students require input in order to produce output. Students need teacher's support in order to engage in tasks across school subjects while focusing on the discourse, lexical, and grammatical components of the academic English language. The formatter will need to create these components, incorporating the applicable criteria that follow [1]. Therefore, in teaching writing, the writer used device called 'Magic \&
Fairy-Tale Dice' (Dice of Magic \& Fairy Tales). Dice is played when teaching writing to stimulate the imagination of students. Their imagination was originally intended to raise student input during the primary level and secondary schools.

They certainly have ever heard of tales that are common at the time a toddler, childhood and adolescence. With the implementation of the dice magic, students were trying to remember the tales they have heard in the past and it triggers in the form of oral language production in advance. It also sparks spoken language then the writer point to be written in L2 (second language, ie English). It turns out learning tools Dices 'Magic \& Fairy-Tale " is helpful in the teaching of writing skills.

The same method is also used for the teaching of 'narrative writing'. As we all know this course requires knowledge and skills, one of which is to create story. The dice according to the writer's observations was able to excite the imagination of students in making poetry.

Observing from Bloom's Taxonomy, instructional media using dice 'Magic \& Fairy-Tale' Cognitivism-based is really dominant. Cognitivism views that the most important thing in learning is not a stimulus-response like in behaviorism, but rather, a change learners' mentality [2]. This media evokes a way of thinking students who previously very dependent on the stimulus-response at the level of secondary education into cognitive, namely pouring abstract concepts become real.

Without the help of instructional media such as dice, a gap that occurs between an abstract concept with the real one will be pretty difficult to solve. When the teachers provide a chance in working individually by meta cognitive strategy using magic and fairy tale dice, then creativity development becomes the psychological factor or aspect that will nearly accompany this method [3].

The impact of the changes is the increasing ability of students who take courses in writing narrative text that the writer teaches. It can be seen by using measurable indicator for the improvement of their writing ability. Before using dice 'magic and fairy-tale' language students are not able to produce the written language at all because they did not have the idea what to start in writing. However, after the use of dice, receptive knowledge of the students is able to be awoken at which that is reflected in their writing ability. Another indicator is the time it takes to write. Prior to the use of dice, more pensive students spend time to think about what to write. After the use of dice, students become familiar with patterns and they spend less time in writing. 
In teaching narrative text, the same may happen to students who simply obtain an idea to pour what they think in the form of pieces of story that can be digested and understood by their classmates who read it. Admittedly, it is not easy to write your ideas in the mother tongue or language of its own, even more so in a foreign language (L2), which is only occasionally spoken. For speakers of English as a foreign language (L2), to produce the language orally and in writing both for writing that is commonplace or writing that is creative (creative writing) not as easy as it does the mother tongue (L1), due to differences factors in kinship language in addition to factors arising linguistic barriers between English and Indonesian.

In spite of these constraints, the observation that the writer did in the classroom for the second course, the students were able to improve writing skills, knowledge and ability to write their narrative text in the English language that has been described on the ability and the time required. What is encouraging from the use of such creative media are students able to achieve competence stipulated in writing narrative text in the Curriculum and Syllabus.

As mention earlier, this study explores the implementation magic and fairy tale dices in improving students' writing ability in narrative text. The writer established a classroom action research under the title "The use magic and fairy tale dices to improve students' ability in writing narrative text". In this research, the writer formulated two main question as the problem of the study : (1) how is the implementation of magic and fairy tile dice in teaching narrative text at first semester students of English department? ; (2) how is the ability of first semester students of English department in writing narrative text?

\section{METHOD}

In this research, the writer conducted Classroom Action Research (CAR) because this method explores practical problem with an aim toward developing a solution to a problem [4].

The writer used this method to identify the improvement of students' ability in writing narrative text after using magic and fairy tale dice, as a way for teachers to investigate teaching and learning issues perceived as relevant to them within the contexts of their own workplaces [5]. A group of the students would be involved to boost students understanding of the narrative text.

The subject of this research was first semester students of English Department Widya Gama Mahakam Samarinda. Based on the observation, The writer chose this subject because the students ability in writing narrative text were poor. To get the information about the students' ability in writing narrative text, the writer used observation and writing test. In observation, the writer examined classroom activities without control and determine them. The other strategy in collecting the data by making a test. It used to measure students achievement after they learned narrative text with magic and fairy tale dice.

To conduct this research, the writer used four cycles of action research ; planning (plan to use magic and fairy tale dice), acting (implementing magic and fairy tale dice in teaching narrative text), observing (the writer observed teaching learning process) and reflecting (the writer analyzed the result). After giving a treatment, the writer gave test to assess the result of students' ability in writing narrative text. In giving score to the students result, the writer used writing score guidance by [6]. Maintaining the Integrity of the Specifications

\section{FINDING AND DISCUSSION}

The objective of this classroom action was the find out how the implementation of magic and fairy tale dice in improving students' ability in narrative text. To implement this, the writer used four cycles which already consist of pre cycle. After conducting magic and fairy tale dice in teaching writing narrative text, the writer got a data in each cycle.

TABLE 1: LEARNERS MEAN SCORE OF WRITING NARRATIVE TEXT IN EACH CYCLE

\begin{tabular}{|c|c|c|c|c|}
\hline \multirow{2}{*}{ Learners } & \multicolumn{4}{|c|}{$\begin{array}{c}\text { Students Narrative } \\
\text { Text }\end{array}$} \\
\hline & Pre Cycle & $1^{\text {st }}$ Cycle & $2^{\text {na }}$ Cycle & $3^{\mathrm{ra}} \mathrm{Cycle}$ \\
\hline 1 & 59 & 65 & 72 & 74 \\
\hline 2 & 40 & 56 & 58 & 71 \\
\hline 3 & 58 & 61 & 68 & 76 \\
\hline 4 & 64 & 66 & 62 & 72 \\
\hline 5 & 45 & 48 & 59 & 67 \\
\hline 6 & 44 & 45 & 52 & 64 \\
\hline 7 & - & 54 & 68 & 72 \\
\hline 8 & 44 & 48 & 56 & 68 \\
\hline 9 & 40 & 40 & 62 & 64 \\
\hline 10 & 42 & - & - & - \\
\hline 11 & 52 & 64 & 68 & 74 \\
\hline 12 & 58 & 60 & 66 & 68 \\
\hline 13 & 52 & 54 & 66 & 74 \\
\hline 14 & 61 & 64 & 68 & 70 \\
\hline 15 & 46 & 48 & 52 & 63 \\
\hline 16 & 55 & 62 & 67 & 71 \\
\hline 17 & 59 & 56 & 65 & 69 \\
\hline 18 & 61 & 64 & 66 & 71 \\
\hline 19 & 44 & 48 & 58 & 67 \\
\hline 20 & 54 & 58 & 64 & 68 \\
\hline 21 & 44 & 56 & 58 & 62 \\
\hline 22 & 51 & 55 & 58 & 63 \\
\hline 23 & 58 & 56 & 62 & 62 \\
\hline 24 & 56 & 58 & 62 & 67 \\
\hline 25 & 72 & 70 & 72 & 74 \\
\hline 26 & 45 & 52 & 58 & 68 \\
\hline 27 & 42 & 48 & 59 & 66 \\
\hline 28 & 48 & 58 & 60 & 67 \\
\hline 29 & 57 & 62 & 66 & 73 \\
\hline 30 & 62 & 64 & 72 & 74 \\
\hline 31 & 52 & 58 & 64 & 69 \\
\hline 32 & - & 48 & 56 & 67 \\
\hline Mean & 49 & 54.4 & 61 & 67 \\
\hline
\end{tabular}

\section{Pre Cycle}

In this cycle, the writer observed teaching learning process and taught using conventional method. To start this section, the writer was opening with talking about popular folklore as warming up. He talked that folklore is kind of narrative and explain about it. In this process, some students still didn't understand about narrative and they didn't have any idea during teaching learning process. After explaining about material, the writer gave a test to the students and was 
followed by 32 students. Based on the calculation in this cycle, the average students score is 49 . It means that students score was low and indicate that students' ability in writing narrative text were poor. In order to make students interested, the writer decided to use magic and fairy tale dice in teaching learning process.

\section{a. The first cycle}

Based on the pre cycle result test, some students' score were poor. They didn't have any idea to write anything in their paper. In this cycle, the writer determined to use magic and fairy tale dice as a teaching strategy to solve this problem. In opening the class, the writer told that they would roll the magic and fairy tale dice and knowing the characters on the dice. As a lecturer, the writer saw the students' passion in following teaching learning process.

To prepare the teaching learning process, the writer conducted four step those are planning, acting, observing and reflecting. After completing the first step related to lesson plan and the material, the writer explain about magic and fairy tale dice. After some students tried to roll this dice, the writer asked the students to create a narrative paragraph based on their dice.

The writer also helped some students who has difficulty to find the vocabulary and allow them to open a dictionary. The result of the mean of the first cycle is 54,4. We could conclude that students score already increase despite the students' average score were still poor.

The problems faced by the writer in this cycle were students' hesitation about grammar and their consistency in creating paragraph. Because of the fact, the writer would continue to the next cycle and still used magic and fairy tale dice in teaching and learning process.

\section{b. The Second Cycle}

In this cycle, the writer still used similar technique to improve students writing narrative text. The writer asked the students about their experience in previous meeting and discussed about their problems in creating sentences. Before the writer explained the characters and the rules of the dice again, he asked the students to pay attention seriously and made a special note as a guidance for them.

During the teaching learning process, the writer asked the students if they had question about their problems in writing narrative text using magic and fairy tale dice. In this cycle, the writer also explained how to construct narrative text and the characteristic of its text. After all of those activities finished, the writer gave a test to the students.

The test results showed much better even though at the first meeting the students got lower score. It could be that the students already familiar with magic and fairy tale dice and they had an idea to create narrative text. In this cycle, the average students score was 61and some students already got fair score. The writer would like continue the research to the next cycle to improve the students score in writing narrative text. He explained again every characters in magic and fairy tale dice and how to create a good sentences with generic structure of narrative text.

\section{c. The Third Cycle}

Before conducting this cycle, the writer planned it seriously to make students more enthusiastic and pay attention about the material. In this cycle, the students still faced the problem about complication and resolution in creating a story. During the teaching learning process, the writer explained magic and fairy tale dice and narrative text carefully and repeated it if any students asked about it.

One of the students asked about generic structure of narrative text and the writer explained clearly that it consist of orientation, evaluation, complication, resolution and reorientation. After applying those activities, the writer gave test to all of the students.

The results of the average students score in this cycle were 67.5. It looked that the students score already better than previous cycle. The writer concluded that the students' ability in writing narrative text was increased after being given magic and fairy tale dice.

After conducting this research, the students were easy to get idea in creating sentences and were enthusiastic in teaching learning process. Because of the result of the average students score already good, the writer decided to stop in this cycle.

\section{CONCLUSION}

Based on the findings of the research, it can be concluded that the use of magic and fairy tale dice was said to be successful in improving students' ability in writing narrative text at first semester students of English Department of Widya Gama Mahakam University. It can be seen from the increase of the students mean score from the pre to the first cycle, of which 49 point at the pre cycle and 54.4 at the first cycle.

Furthermore, magic and fairy tale dice is also advised to be helpful to improve students' ability in writing narrative text. It can be seen from the students' interest in creating narrative text. Additionally, magic and fairy tale dice was very useful to be a booster of students' imagination and motivation in creating narrative text.

The conclusion of this research is supposed to be as an additional technique to the lecturer/teacher in teaching writing especially narrative text. The use of magic and fairy tale dice in teaching narrative text is one of attractive media to boost students' motivation and interest. The result of this research are also hopefully as a new insight and valuable information for lecturers/teachers especially in teaching writing.

\section{REFERENCES}

M. M. Alameddine and H. S. Mirza, "Teaching Academic Writing for Advanced Level Grade 10 English," Procedia - Soc. Behav. Sci., vol. 232, pp. 209-216, 2016.

E. C. Soo, "Importance of ongoing motivation for EFL writers' performance : growth curve modeling," J. Asiat., vol. 13, no. 4, pp. 280-293, 2016.

3] K. Soraya, "The Effectiveness of Collaborative Writing Strategy (CWS) in Writing Lesson Regarded 
to the Students' Creativity," Ling. Cult., vol. 10, no. 2, pp. 63-67, 2016.

[4] J. W. Creswell, Educational Research: Educational Research: Planning, Conducting, and Evaluating Quantitative and Qualitative Research, 4th ed. Lincoln: Pearson, 2012.

5] A. Burns, A. Westmacott, and A. H. Ferrer, "Initiating an action research programme for university EFL teachers: Early experiences and responses," Iran. J. Lang. Teach. Res., vol. 4, no. 3, 2016.

[6] A. Hughes, Testing for Language Teachers. New York: Cambridge University Press, 1989. 